\title{
EXOTIC TREES IN CANADA
}

\author{
By G. A. Mulloy, B.Sc.F. \\ Assistant Chief, Division of Silvicultural Research
}

$\prod$

HE definition of exotic trees as those belonging by origin, nature or characteristic to another part of the world, or as brought in from abroad has to be somewhat revised in the case of Canada to give consideration to its size and the varied nature of the climate. It is to be expected, in a country so varied as ours, that the tree species indigenous to one section are looked upon as true exotics when planted in another section. In this discussion, therefore, any species introduced into any section of the Dominion from a different vegetative belt is considered an exotic to the same extent as if it came from another country.

Canada covers about eighty degrees in longitude, and reaches from about forty degrees north latitude to beyond the Artic circle. The climate for the greater part of the interior may be said to be continental, alhough much of the eastern portion is greatly modified by the presence of the Great Lakes, and the intrusion of Hudson Bay from the north. The eastern Atlantic section has a modified maritime climate, the winters being colder than is generally found in countries adjacent to the ocean. On the west the immediate coast section has a true maritime climate, comparable to that of northwestern Europe. This area is limited by the high mountain ranges which parallel the coast, at a comparatively short distance from it. From the Rocky mountains, the whole land surface of the Dominion slopes gradually eastward and northward, the elevations varying from 3,000 feet in the foot-hills of Alberta, to 1,000 feet in Manitoba. In the eastern section the Laurentian plateau forms an elevation of about 1,000 feet which slopes eastward and northward.

Precipitation in Canada, as a consequence of its topography, is very varied. The coast belt in British Columbia has over 100 inches of annual rainfall; yet a short distance away in the inter-mountain dry belt the fall is about ten inches. From the prairies of western Canada to the Atlantic seaboard the rainfall gradually increases from twenty inches to a maximum of forty or fortyfive inches. Of course this precipitation varies seasonably. On the Pacific coast the enormous precipitation occurs mostly during the winter months; on the prairies the scanty rainfall occurs during the spring with scattered showers during the early summer. In the interior, surrounding the lower part of Hudson Bay, the winter precipitation is not nealy as great as the summer; and further south, in the peninsula of old Ontario, there is small change throughout the year. This latter is true also of the Atlantic maritime section.

The greater part of the Dominion is in the north temperate zone; in the far north, Arctic conditions obtain. Southern Ontario and a small section of the coast of British Columbia have southern temperate zone characteristics. It is in these latter two zones that there is the smallest fluctuation between 
winter and summer temperature; as a consequence many trees grow in these sections which cannot be grown elsewhere. The annual range of temperature in the interior of the Dominion is very great, varying from a maximum of ninety degrees above zero in summer to a minimum of thirty and forty degrees below zero in winter.

There is a number of species whose natural habitat is confined to British Columbia, and which can be grown only in restricted areas outside of that habitat. The Douglas Fir (Pscudotsuga taxifolia) from some parts of its range, Sitka spruce (Picen sitchensis), and ponderosa pine ( $P$ inus ponderosa) can be grown in the east as far north as Ottawa. Although they do not grow as rapidly as in their native habitat, good specimens are to be found growing on the Central Experimental Farm at Ottawa. These species, however, cannot be grown on the prairies of the West.

Ponderosa pine has been tried at Grand'Mère in Quebec, but it was consistently winter-killed in the nursery. In the Sprucewoods Forest Reserve in Manitoba it grows to about two feet in height and then is consistently killed back.

All of the Eastern species, both conifers and broad-leaved trees, can be grown in the mild climate of the British Columbia coast, and the scarcity of the hardwoods in the flora of this latter district has caused many of the commoner species to be planted, mostly as ornamentals or as street shade trees.

Several efforts have been made to extend northward the natural range of the native black walnut (Juglans nigra), which is indigenous to the southern peninsula of Ontario. These efforts have met with some success in sheltered valleys and on good soil.

There is a large field for experimentation in the east with frost-hardy strains of the various conifers of British Columbia, such as Douglas fir, the true firs, ponderosa pine, Western white pine, and lodgepole pine. Some of the damage from insects and fungi to which the Eastern species are susceptible may be circumvented in this manner.

A rather extensive inquiry into the use of exotic trees in Canada reveals that, as far as their use in forest plantations is concerned, it has been confined to Scots Pine (Pinus sylvestris) and Norway Spruce (Picen excelsa), and even these species were used only during the earlier stages of planting activities in Canada.

During the early stages of forest nursery development, the sole source of seed or seedlings of forest trees was Europe. Consequently most of the earlier efforts at planting were made with stock produced from European seed. It was some time before seed collecting from our native species was organized, but as soon as seed from North American species became available it rapidly replaced that from Europe. 
However, some of these earlier plantations of Scots pine and Norway spruce are now over twenty years of age, and some useful information can be obtained as to the value of these species as forcst trees. It became apparent very early that the source of the seed of both these species was important, and unfortunately in many cases the origin of the seed has influenced unfavourably the reaction to these species in this country. Often the planting stock was received from some forest nursery in the United States, and the origin of the seed was not known. But from resultant growth it was evident that no care had been taken to obtain seed from northern Europe. As a consequence, the trees developed poor form, were subject to killing back, or had other undesirable qualities.

Planting of forest trees over large areas has been carried on for the last twenty years or so, particularly in Ontario and Quebec. Both of these provinces, have large nurseries, and do considerable planting. In Quebec several of the pulp and paper companies have undertaken planting. As indicated above, at the outset, owing to the lack of seed from indigenous species, the initial work was with Norway spruce and Scots pine.

Norway Spruce.-A paper company in Quebec planted a large araa with Norway spruce during the first few years of its activity, but later changed to native white spruce (Picea glauca) because, owing to various causes, the Norway spruce did not seem to promise as good results as the native white spruce. As it turned out later, much of the earlier unfavourable experience with Norway spruce may have been due to the planting sites selected, the poor method of planting, and subsequent care. Where care was taken in planting, and where release operations were conducted after planting on cut-over hardwood lands, the growth has been splendid. One such plantation made in 1914 with 2-2 stock (that is, trees which after two years' growth in the nursery had two years in transplant beds) now contains, on a one-tenth acre plot, 131 trees which average about 17.1 feet high and 3.6 inches in diameter. The following table shows better the distribution of this plantation measured when 17 years old ( 21 years from seed) in height- and diameter-classes.

NORWAY SPRUCE PLANTATION, GRAND-MERE, QUEBEC

\begin{tabular}{|c|c|c|c|c|c|}
\hline Height-classes & $\begin{array}{l}\text { No. of } \\
\text { Trees }\end{array}$ & $\begin{array}{l}\text { Per } \\
\text { cent }\end{array}$ & $\begin{array}{l}\text { Dia- } \\
\text { meter- } \\
\text { classes }\end{array}$ & $\begin{array}{l}\text { No. of } \\
\text { Trees }\end{array}$ & $\begin{array}{l}\text { Per } \\
\text { cent }\end{array}$ \\
\hline \multirow{3}{*}{ 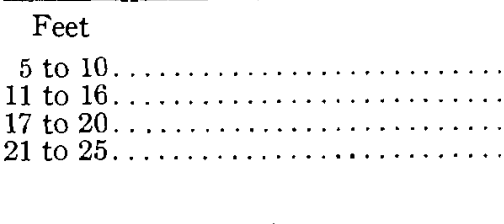 } & & & Inches & & \\
\hline & $\begin{array}{l}14 \\
27 \\
66 \\
24\end{array}$ & $\begin{array}{l}11 \\
21 \\
50 \\
18\end{array}$ & $\begin{array}{l}l \text { to } 2 \\
3 \text { to } 5 \\
6 \text { to } 8\end{array}$ & $\begin{array}{r}15 \\
114 \\
2\end{array}$ & $\begin{array}{r}11 \\
87 \\
2\end{array}$ \\
\hline & 131 & 100 & $\ldots \ldots$ & 131 & 100 \\
\hline
\end{tabular}


In the case of another plantation on ploughed land, where Norway spruce and native white spruce were planted side by side under the most favourable conditions, the Norway spruce is actually growing faster than the white and has a more cylindrical form.

While these data may not be said to be representative of the major part of the earlier work with Norway spruce, they do indicate what results would have been obtained with proper care subsequent to planting. Under the conditions obtaining in the earlier plantation work, it is doubtful wheher any other coniferous species would have done any better. Much of the land planted in the earlier work was recently cut-over hardwood lands. A smothering crop of sprouts and suckers developed which, with the damage from rabbits, resulted in a stunted condition of the Norway spruce. It is possible, then, that under reasonably favourable conditions the Norway spruce will grow as well in this district as the native white spruce.

Scots Pine.-As with Norway spruce, the earlier planting work was started with Scots pine because seed from the native species was not available. Seed in most cases was obtained from commercial sources, and its origin was unknown. Some time elapsed before the importance of obtaining seed from the best stands of Europe became apparent. The quick growth of this pine at first created a favourable inipression, but soon the type of bole produced created a very unfavourable reaction, with the result that very little of it is planted now. The Ontario Government at its nurseries at St. Williams in southern Ontario is, however, experimenting with some seed obtained from the best sources in Europe and Great Britain, but it will be some time before the results become available.

The list of introduced species in the following pages shows that in the aggregate a large number of exotic species have been grown singly or in groups at various points throughout the Dominion, at agricultural experimental stations as ornamentals or in arboreta. While this does not show their usefulness from a forestry standpoint, and even in certain cases does not prove their hardiness, yet it is from these data that the possibilities of certain species as forest growth may be gauged to some extent.

Generally speaking, it cannot be said that any of the exotic species have as yet shown such remarkable qualities or superiority to the natjve species, either in growth or freedom from disease, as to warrant their general use in plantation work. One exception to this seems to be the European and the Japanese larches, as well as the hybrid of these two species. The eastern tamarack (Larix laricina), which was almost totally destroyed some years ago by the larch sawfly, seems to be of slower growth than the exotic varieties. But these latter suffer from the sawfly as well. If the sawfly can be con- 
trolled, then exotic varieties may become valuable additions to the forests of Canada.

A recent development in Canada is the experimentation with hybrid poplars. Aspen and other poplars have become valuable both as splint stock for matches and as pulpwood. The native varieties, while of fairly quick growth, suffer much from rot, especially on certain sites. The Petawawa Forest Experiment Station of the Department of the Interior at Chalk River, Ontario, is experimenting with a large number of hybrid poplars. This work is not far enough advanced for the data to be of value, but some of the varieties and hybrids show great promise.

In the subjoined list of exotics the botanical names are, for the greater part, taken from Alfred Rehder's "Manual of Cultivated Trees and Shrubs." Where the species is reported under a different botanical name, this is given as a synonym.

Trees designated as planted at Sidney, B.C., are in the arboretum of the experimental station at Sidney, on Vancouver island, not far from the provincial capital, Victoria, and almost at the southern extremity of the island. Trees listed as planted at Ottawa, Onario, are in the arboretum or on the grounds of the Central Experimental Farm. Those designated as planted at Indian Head, Saskatchewan, are in the grounds or the plantations of the Indian Head Forest, Nursery. Those at Morden, Manitoba, and Kentville, Nova Scotia, are on the grounds of the experimental farms at these points.

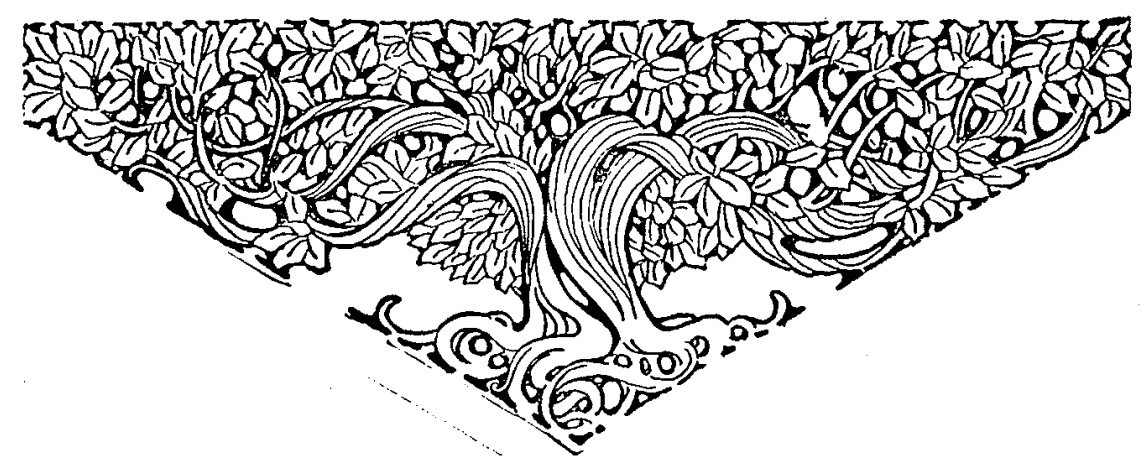

